\title{
Magnetic Fields in Food Processing Perspectives, Applications and Action Models
}

\author{
Hubert Luzdemio Arteaga Miñano ${ }^{1}\left(\mathbb{D}\right.$, Ana Carolina de Sousa Silva ${ }^{2} \mathbb{(}$, Sergio Souto ${ }^{2}(\mathbb{C}$ \\ and Ernane José Xavier Costa ${ }^{2, *(D)}$ \\ 1 Department of Engineering and Agroindustrial Management, Faculty of Agricultural Sciences, Campus \\ Colpa Huacariz, National Autonomous University of Chota, Chota 06121, Peru; hlarteagam@unach.edu.pe \\ 2 Department of Basic Science, Faculty of Animal Science and Food Engineering, Campus Fernando Costa, \\ University of São Paulo, Pirassununga 13635-900, Brazil; anacss@usp.br (A.C.d.S.S.); Ssouto@usp.br (S.S.) \\ * Correspondence: ernane@usp.br
}

Received: 11 June 2020; Accepted: 7 July 2020; Published: 10 July 2020

\begin{abstract}
Magnetic fields (MF) are increasingly being applied in food processing to preserve food quality. They can be static (SMF), oscillating (OMF) or pulsed (PMF) depending on the type of equipment. The food characteristics can be influenced by several configurations of the applied magnetic field as its flux density, frequency, polarity and exposure time. Several mechanisms have been proposed to explain the effects of magnetic fields on foods. Some of them propose interactions at the subatomic particle level that show quantum behavior, such as the radical pair and cyclotron resonance mechanisms. Other proposals are at the level of DNA, compounds, subcellular organelles and cells. The interactions between food and magnetic fields are addressed in a general way in this work, highlighting the applications and action models involved and their effects on the physicochemical, enzymatic and microbiological characteristics of food.
\end{abstract}

Keywords: electromagnetic fields; physicochemical characteristic; enzyme activity; microorganism inactivation; magnetic fields mechanisms

\section{Introduction}

Emerging technologies, alone or combined, are focused on improving food processing. Among them are magnetic fields (MFs), which have been applied to the enzymes, microorganisms and quality of foods [1-4]. However, conflicting results on their performance have been reported $[5,6]$ and it has been suggested that MFs can act through the window effect [7] and through the underlying effects of field gradients on specific biological goals [8]. Compared with other techniques, the main advantage of the magnetic field is the way it interacts with the food that encompasses both thermodynamic aspects and quantum effects. The way the interaction occurs is not yet clear, so understanding the models of action of MFs on processing foods has become a challenge. This communication is focused on describing the applications of MFs in food processing, emphasizing the magnetic variables involved such as the magnetic flux density, frequency and exposure time, among others and moreover, the suggested action models that are behind those effects

Understanding them could lead to improvements in transformation and conservation processes in the food industry.

\section{Procedural Principles and Technical Aspects of Magnetic fields}

MFs are generated by electric currents direct or alternating (AC/DC) in conductors or by permanent magnets. According to their behavior over time, they may be static magnetic field (SMF), oscillating 
(OMF) or pulsed (PMF). The spatial distribution of an MF may be homogenous if the field gradient is zero over the space where samples are exposed or heterogeneous in other cases [9].

Considering the magnetic flux density, SMFs are classified as super weak (100 nT to $0.5 \mathrm{mT}$ ), weak $(<1 \mathrm{mT})$, moderate ( $1 \mathrm{mT}$ to $1 \mathrm{~T})$, strong ( 1 to $5 \mathrm{~T})$ and ultra-strong $(>5 \mathrm{~T})$ [10]. With regard to EMFs and PMFs, the factors considered are the magnetic flux density, frequency, waveform, exposure time and polarity [7]. In the function of frequency, they are considered as extremely low frequency ( 0 to $300 \mathrm{~Hz}$ ), intermediate frequency ( $300 \mathrm{~Hz}$ to $1 \mathrm{MHz}$ ), radio frequency $(1 \mathrm{MHz}$ to $500 \mathrm{MHz}$ ), microwave frequency (500 MHz to $10 \mathrm{GHz}$ ) and high frequency (>10 GHz) [1].

The interaction of an MF with a biological system such as food depends on physical quantities and system characteristics such as resistivity, electrical conductivity, thickness and magnetic susceptibility [9] and this dependence can be modeled according to Equations (1) and (2). The main components of foods and cells can be modeled as a charged system in motion. So, the Lorentz force (FL) can act on them (Equation (3)) if the applied MF is strong enough. In fact, the main force acting on such magnetic components of cells is the electric force (FE) under an SMF because FL $<<$ FE [8]; however FL in intracellular components (diamagnetic and paramagnetic) can have an important role that needs to be investigated. In addition, for a component with volume $V$ and magnetic susceptibility $x$, the magnetic force (FGM) arising from a time-variant magnetic field interacting with a magnetic dipole in a certain medium is presented in Equations (4) and (5), respectively. The magnetic force FGM may be responsible for activating certain mechanisms in the cell's compounds that modify its structure and functionality [8].

$$
\begin{gathered}
\vec{B}=\mu_{0}(\vec{H}) \\
\vec{M}=\chi_{m} \vec{H} \\
\vec{F}_{L}=q \vec{v} \times \vec{B} \\
\vec{F}_{G M}=\vec{p}_{m} \frac{d \vec{B}}{d l} \\
\vec{F}_{G M}=\frac{\Delta \chi_{v}}{\mu_{0}} \nabla\left(\vec{B}^{2}\right) \rightarrow f_{G M z}=\frac{\left(\chi_{v 1}-\chi_{v 2}\right)}{\mu_{0}} B_{z} \frac{d B_{z}}{d z},
\end{gathered}
$$

where $\vec{H}$ = magnetic field intensity $(\mathrm{A} / \mathrm{m}), \vec{B}=$ magnetic flux density $(\mathrm{T}), \vec{M}=$ magnetization $(\mathrm{A} / \mathrm{m})$, $\mu_{0}=$ magnetic permeability of the vacuum $(\mathrm{H} / \mathrm{m}), \chi_{m}=$ mass magnetic susceptibility $\left(\mathrm{m}^{3} / \mathrm{kg}\right), \chi_{v}=$ volumetric magnetic susceptibility (dimensionless), $\vec{p}_{m}$ = magnetic dipole moment of charged particle, $l=$ direction parallel to the magnetic dipole moment of a charged particle $(\mathrm{m}), q=$ charged particle, $\vec{v}$ $=$ velocity of charged particle $(\mathrm{m} / \mathrm{s})$.

\section{Magnetic Field and Its Interaction with the Physicochemical Properties of Foods}

The physicochemical characteristics of food are related to its compounds, which include mainly water, proteins, carbohydrates, fiber, lipids and minerals. However, the investigations carried out so far on the application of MFs to foods have been described as a black box, except in water, where there is information on MF effects. Table 1 summarizes the MF effects. 
Table 1. Overview of oscillatory (OMF), static (SMF) and pulsed (PMF) magnetic fields effect on physicochemical characteristics of selected food products.

\begin{tabular}{|c|c|c|c|c|c|}
\hline Product & Characteristics & Equipment & Experimental Conditions & Main Results & Ref. \\
\hline $\begin{array}{l}\text { Cantaloupe } \\
\text { melon cut }\end{array}$ & $\begin{array}{c}\text { Firmness, Soluble solids, } \\
\text { Respiration rate, } \\
\text { Electrolyte leakage, } \\
\text { Titratable acidy }\end{array}$ & OMF & $\begin{array}{l}\text { B: } 2 \mathrm{mT} \\
\quad \mathrm{f}:- \\
\mathrm{t}: 0-25 \mathrm{~min}\end{array}$ & $\begin{array}{l}\text { At } 15 \mathrm{~min} \text {, maintain the } \\
\text { quality until } 4 \text { days at } 5^{\circ} \mathrm{C} \text {. }\end{array}$ & [5] \\
\hline Cheese & $\begin{array}{l}\text { Yield and sensory } \\
\text { characteristics }\end{array}$ & SMF & $\begin{array}{l}\text { B: } 0.365 \mathrm{~T} \\
\text { t: } 0-60 \mathrm{~min}\end{array}$ & $\begin{array}{l}\text { Increased and better } \\
\text { acceptability }\end{array}$ & [10] \\
\hline Strawberry & Yield of fruits & OMF & $\begin{array}{c}\text { B: } 0.096-0.384 \mathrm{~T} \\
\text { f: } 50 \mathrm{~Hz}\end{array}$ & $\begin{array}{c}\text { Increased at } 0.096 \mathrm{~T} \text { after } \\
\text { decreased }\end{array}$ & [4] \\
\hline Honey & $\begin{array}{l}\text { Rheological and } \\
\text { physicochemical } \\
\text { characteristics }\end{array}$ & SMF & $\begin{array}{c}\text { B: } 117.3,192.9 \text { and } 228.9 \\
\mathrm{mT} \\
\mathrm{T}: 15,28^{\circ} \mathrm{C} \\
\mathrm{t}: 2 \mathrm{~h}\end{array}$ & $\begin{array}{l}\text { Improve flowability and } \\
\text { maintaining its } \\
\text { physicochemical quality }\end{array}$ & [7] \\
\hline Ground beef & $\begin{array}{l}\mathrm{pH}, \text { Color, Myoglobin, } \\
\text { lipid oxidation }\end{array}$ & PMF & $\begin{array}{l}\text { B: } 10 \mathrm{mT} \\
\mathrm{f}: 1 \mathrm{~Hz} \\
\mathrm{t}: 0-12 \text { days }\end{array}$ & At $1 \mathrm{~Hz}$ for $2 \mathrm{~h}$ preserved & [6] \\
\hline Apple & $\begin{array}{l}\text { Content of fructose and } \\
\text { glucose }\end{array}$ & PMF & $\begin{array}{l}\text { B: } 50-150 \mu \mathrm{T} \\
\text { f: } 10-100 \mathrm{~Hz} \\
\text { t: } 5 \mathrm{~min} / \text { Week }\end{array}$ & $\begin{array}{l}\text { Increase by } 8 \% \text { fructose } \\
\text { and } 25 \% \text { glucose }\end{array}$ & [11] \\
\hline
\end{tabular}

Each compound of the food is formed from atoms and molecules. When an MF is applied to it, depending on its isotropy and magnetic susceptibility $\chi$, if $\chi<0$ it is diamagnetic otherwise it is paramagnetic, it has different behavior. Thus, carbon atoms exhibit isotropic susceptibility but organic molecules present in food have anisotropic susceptibility [1]. Therefore, the properties of the molecules and compounds of food should be determined, which will help to understand the effects of an MF on the physicochemical characteristics of foods. With regard to this property, Maki and Hirota [2] succeeded in completely separating sorbitol and sucrose in compressed oxygen gas by applying a gradient MF, which was possibly due to the $8.2 \%$ difference in magnetic susceptibility between them.

In cherry tomatoes, the average weight and content of lycopene and total soluble solids increased with MF and were greater within a PMF than with a SMF [3]. Also, Eşitken and Turan [4] reported that MF stimulation of strawberries was able to increase the plant metabolism and the number of ions in the leaves that were corroborated by work of Jia et al. [5] that reported that an OMF significantly prolonged the shelf life of cantaloupes by slowing respiration. Lins et al. [6] reported that PMF prevented possible changes in the oxidative state of the iron atom of the harem group, decreasing the rate of oxidation of $\mathrm{Fe}^{2+}$ to $\mathrm{Fe}^{3+}$ and hence allowing the ground beef to keep its color for a longer time.

In honey, the application of an MF decreased the $\mathrm{pH}$ and increased the soluble solids by breaking up macromolecules like pollen, which facilitated the release of ascorbic acid and sugars [7]. On the other hand, Otero et al. [8] reviewed the effects of MFs on the freezing of biological products, reaching the conclusion that many doubts remain about the effectiveness of low-intensity MFs $(<1 \mathrm{mT})$ on the crystallization of water and suggested that the range of strength and frequency should be increased. Indeed, Zhao et al. [9] reported that strong magnetic fields may harm cell properties and should not be used to preserve biological samples and fresh food. However, a weak magnetic field $(<0.5 \mathrm{mT})$ is not effective either but when the MF strength exceeds $1 \mathrm{mT}$, its application may play a significant role in food freezing and preservation at the low cost of implementation.

An Overview of the effects of magnetic fields on the physicochemical characteristics of foods is summarized in Table 1.

\subsection{Effects of Magnetic Fields on Food Enzymes}

Enzymes are proteins that have a specific activity in food, which can be beneficial or harmful to the quality of the food. Therefore, choosing the action levels of an MF will depend on whether we want to stimulate or inactivate the enzymes. MFs can change the structure of enzymes, affecting the related biochemical processes. This fact was reported by Jia et al. [12], who showed changes in four secondary conformations of $\alpha$-amylase when it was subjected to an SMF. Likewise, in peroxidase under a PMF, conformational changes were evaluated by UV and confirmed by fluorescence spectra [13]. Also, 
it is suggested by Buchachenko [14] that biochemical reactions are controlled by the angular moment and energy, with the first being more strict as its spin state selectivity is identical in reactants and products and when is an atomic forbidden state it can be overcome by synchronized spin with an MF. In general, biochemical reactions that involve more than one unpaired electron will be affected by an MF [15]. Mizuki et al. [16] mention that to increase the enzymatic activity it is necessary to synchronize the relative motion between enzymes and substrate molecules. They did it by immobilizing enzymes using magnetic particles to control the movement of the enzymes through the frequency used in the MF. At a frequency of $5 \mathrm{~Hz}$, an MF can increase the activity of $\alpha$-amylase [17].

The main results of the effects of MFs on the enzymes of interest in the food industry that can be used to improve the action models are summarized in the Table 2.

Table 2. Overview of oscillatory (OMF), static (SMF) and pulsed (PMF) magnetic fields effect on enzymes of foods.

\begin{tabular}{|c|c|c|c|c|c|}
\hline Food/Substrate & Enzyme & Equipment & Experimental Conditions & Main Results & Ref. \\
\hline Starch & $\alpha$-amylase activity & OMF & $\begin{array}{c}\text { B: } 12 \mathrm{mT} \\
\text { f: } 1-30 \mathrm{~Hz} \\
\text { t: } 30 \mathrm{~min}\end{array}$ & $\begin{array}{l}\text { Increased being } \\
\text { higher at } 5 \mathrm{~Hz}\end{array}$ & [17] \\
\hline Glycine max L. Merr. Roots & Catalase activity & SMF & $\begin{array}{l}\text { B: } 2.9-4.6 . \mathrm{mT} \\
\text { t: } 2.2-33 \mathrm{~s}\end{array}$ & Increased & [15] \\
\hline Fruits and vegetables & PPO activity & PMF & $\begin{array}{c}\text { B: } 2.5-4.5 \mathrm{~T} \\
\text { Pulses: } 5-40 \\
\text { H: } 12 \mathrm{mT}\end{array}$ & $\begin{array}{c}\text { Decreased by } \\
93.10 \%\end{array}$ & [13] \\
\hline p-nitrophenyl palmitate & Lipase activity & OMF & $\begin{array}{c}\mathrm{f}: 1-30 \mathrm{~Hz} \\
\mathrm{t}: 30 \mathrm{~min}\end{array}$ & Increased & [16] \\
\hline $\begin{array}{l}\text { Methoxyphenol and hydrogen } \\
\text { peroxide }\end{array}$ & Peroxidase activity & PMF & $\begin{array}{c}\text { B:2-4T } \\
\text { Pulses:5-40 }\end{array}$ & $\begin{array}{c}\text { Decreased by } \\
\quad 67.67 \%\end{array}$ & [13] \\
\hline
\end{tabular}

\subsection{Effects of Magnetic Fields on Microorganisms of Foods}

The main objective of the application of MFs to microorganisms is to reduce the content of species that are pathogenic or that deteriorate foods and to stimulate the growth of beneficial strains to produce fermented foods. For the inactivation of microorganisms in sealed foods, Barbosa-Cánovas et al. [18] suggest the use of PMF conditions ranging from 5 to $50 \mathrm{~T}, 1$ to 100 pulses, 5 to $500 \mathrm{~Hz}, 0$ to $50{ }^{\circ} \mathrm{C}$ and 25 to $100 \mu \mathrm{s}$ of exposure time, reduced the microorganism growth by at least $2 \log$ (CFU) (Colony Formation Unit). Liu et al. [19] argue that an MF acts on the passivation of cells, which inhibits their growth and reproduction. Low-frequency MFs have a great impact on cells and tissues and low frequency; high-intensity PMFs destroy microbial cell membranes and organelles. Thus, Ji et al. [20] showed damage to the cell membrane of E. coli after the application of an SMF. Membrane channels of E. coli is affected by SMF as reported by Strašák et al. [21] they concluded that an SMF has a bactericidal effect since it forms free radicals that attack cell membrane. Wu et al. [22] state that changes in expression and stability of intracellular proteins can be another way by which Listeria strains may be inactivated when subjected to a PMF. Besides, Bayraktar [23] reported that an OMF changes the activity of enzymes in Saccharomyces cerevisiae, limiting its growth and even causing the death of some individuals. However, after being subjected to MFs, survivors have higher activity, which is also related to potassium, calcium and magnesium levels. When an SMF was applied to Saccharomyces cerevisiae ethanol production was [24], suggesting that the ethanol-glucose conversion mechanisms were probably modified.

On the other hand, Masakazu et al. [25] reported that in fermentation it is important to consider the paramagnetic behavior of oxygen molecules and the diamagnetic behavior of carbon dioxide under an MF, which limited the mass transfer. In Lactococcus lactis, the application of an MF led to a deviation of the metabolic pathway in order to intensify or to inhibit nisin production [26].

The differentiated results of MFs on microorganisms have led to the hypothesis that they act under the window effect, which implies that specific parameters can be tuned for each microorganism [27-29]. Thus, in Staphylococcus aureus, a PMF of $1.5 \mathrm{mT}$ and $300 \mathrm{~Hz}$ is suggested [30]. Moreover, the growth phase, shape and type of cell, eukaryotic or prokaryotic, should be considered [31]. 
Table 3 presents an overview of the effects of an MF on microorganisms of interest in the food industry applied to both food and nutritive broth.

Table 3. Overview of oscillatory (OMF), static (SMF) and pulsed (PMF) magnetic fields effect on microorganisms of foods.

\begin{tabular}{|c|c|c|c|c|c|}
\hline Food/Medium & Microorganism & Equipment & Experimental Conditions & Main Results & Ref. \\
\hline Cheese whey permeate & $\begin{array}{l}\text { Lactococcus lactis growth. } \\
\text { Nisina production }\end{array}$ & SMF & $\begin{array}{c}\text { B: } 5-20 \mathrm{mT} \\
\text { v: } 0.85-1.5 \mathrm{~m} / \mathrm{s} \text { (recycling) } \\
\text { t: } 4-12 \mathrm{~h}\end{array}$ & $\begin{array}{l}\text { Increased at } 5 \mathrm{mT} \text {, } \\
1.5 \mathrm{~m} / \mathrm{s} \text { and } 4 \mathrm{~h}\end{array}$ & [26] \\
\hline TY broth & Escherichia coli growth. & OMF & $\begin{array}{c}\text { B: } 2.7-10 \mathrm{mT} \\
\mathrm{f}: 50 \mathrm{~Hz} \\
\mathrm{t}: 0-12 \mathrm{~min}\end{array}$ & Decreased & [21] \\
\hline Luria-Bertani medium & Escherichia coli growth. & SMF & $\begin{array}{l}\text { B: } 45-3500 \mathrm{mT} \\
\text { (homogeneous) } \\
\text { t: } 0-60 \mathrm{~min} \\
\text { v: } 120 \text { strokes/min }\end{array}$ & $\begin{array}{l}\text { At } 450 \mathrm{mT} \\
\text { decreased } \\
\text { exponentially with } \\
\text { the time exposure } \\
\text { and temperature. }\end{array}$ & [20] \\
\hline Nutrient broth & Escherichia coli growth & PMF & $\begin{array}{c}\text { B: } 0-4.5 \mathrm{~T} \\
\text { f: } 50 \mathrm{~Hz} \\
\text { t pulse: } 1-6 \mathrm{~ms} \\
\text { Pulses: } 0-40 \\
\text { B: } 18 \mathrm{~T}\end{array}$ & Decreased by $18 \%$ & [29] \\
\hline $\begin{array}{l}\text { Phosphate buffer } \\
\text { Mcllvaine buffer } \\
\text { Peptonized water }\end{array}$ & $\begin{array}{c}\text { Escherichia coli } \\
\text { Saccharomyces cerevisiae } \\
\text { growth }\end{array}$ & PMF & $\begin{array}{l}\text { f: } 10-15 \mathrm{kHz} \\
\text { t pulse: } 20-40 \mathrm{us} \\
\text { Pulses: } 0-50 \\
\text { t: } 52 \mathrm{~min}\end{array}$ & $\begin{array}{l}\text { Not inactivation } \\
\text { for both }\end{array}$ & [28]) \\
\hline Nutrient & $\begin{array}{c}\text { Escherichia coli } \\
\text { Staphylococcus aureus } \\
\text { Saccharomyces cerevisiae } \\
\text { Bacillus subtilis growth }\end{array}$ & PMF & $\begin{array}{c}\text { Glass vial } \\
\text { B: } 1.29-9.48 \mathrm{~T} \\
\text { Pulses:5-35 } \\
\text { Static tube } \\
\text { B: } 2.11-3.79 \mathrm{~T} \\
\text { Pulses: } 20\end{array}$ & $\begin{array}{l}\text { Results varied in } \\
\text { either them }\end{array}$ & [27] \\
\hline $\begin{array}{l}\text { Liquid medium } \\
\text { (Peptone-Glucose) }\end{array}$ & $\begin{array}{l}\text { Saccharomyces cerevisiae } \\
\text { growth }\end{array}$ & SMF & $\begin{array}{c}\text { B: 5-14T (inhomogeneous } \\
\text { dB/dx: } 94 \mathrm{~T} / \mathrm{m} \text { ) } \\
\text { Angle: } 15^{\circ} \\
\text { T: } 30^{\circ} \mathrm{C} \\
\text { v: } 120 \text { strokes } / \text { min }\end{array}$ & $\begin{array}{l}\text { Decreased after } 16 \\
\text { h of incubation }\end{array}$ & [25] \\
\hline Growth medium & $\begin{array}{l}\text { Saccharomyces cerevisiae } \\
\text { growth }\end{array}$ & SMF & $\begin{array}{l}\mathrm{B}: 220 \mathrm{mT} \\
\mathrm{t}: 24 \mathrm{~h}\end{array}$ & Increased & [24] \\
\hline Grape must & $\begin{array}{c}\text { Saccharomyces cerevisiae } \\
\text { growth }\end{array}$ & OMF & $\begin{array}{l}\text { B: } 5 \mathrm{mT} \\
\mathrm{f}: 160 \mathrm{~Hz} \\
\mathrm{t}: 30 \mathrm{~min}\end{array}$ & Decreased & [23] \\
\hline Malt extract broth & $\begin{array}{l}\text { Saccharomyces cerevisiae } \\
\text { growth }\end{array}$ & OMF & $\begin{array}{l}\text { B:10 mT } \\
\text { f: } 50 \mathrm{~Hz} \\
\text { t: } 24 \mathrm{~min}\end{array}$ & Decreased & [31] \\
\hline Nutrient broth & Bacillus subtilis growth & PMF & B: 3-3.3 T Pulses:5-30 & Decreased & [32] \\
\hline Lysogeny broth & Listeria grayi growth & PMF & $\begin{array}{c}\text { B: } 1-3.5 \mathrm{~T} \\
\text { Pulses: } 10-35\end{array}$ & $\begin{array}{l}\text { Better inactivation } \\
\text { to } 2.5 \mathrm{~T} \text { with } 25 \\
\text { pulses }\end{array}$ & [22] \\
\hline Columbia & $\begin{array}{l}\text { Staphylococcus aureus } \\
\text { growth }\end{array}$ & PMF & $\begin{array}{l}\text { B: } 0.5-2.5 \mathrm{mT} \\
\text { f: } 2-500 \mathrm{~Hz} \\
\text { t: } 90 \mathrm{~min}\end{array}$ & Decreased & [30] \\
\hline Liquid Charles & Aspergillus Niger growth & OMF & $\begin{array}{l}\text { B: } 0.2-1 \mathrm{mT} \\
\text { f: } 50 \mathrm{~Hz} \\
\text { t: } 4-8 \mathrm{~h}\end{array}$ & Increased & [33] \\
\hline
\end{tabular}

\section{Main Action Models of Magnetic Fields on Foods}

The effect of MFs on food, since it is complex biological systems, follows a hierarchy from the atomic and molecular level to the system level, with the last level depending on the interaction of the first two levels [34]. Several action models of the effects MFs on biological systems have been proposed [35-37]. However, experimental evidence to confirm them is lacking, especially in foods, where there are few reports on this topic. The main action models proposed will describe in the next sections.

\subsection{Radical Pair (RP)}

This action model is related to radicals, where an MF can induce spin singlet-triplet transitions in each of them, changing its reactivity [34]. Therefore, MF can change a series of reactions that occur 
within foods. Because radical pair (RP) recombination and diamagnetic anisotropy act only on elements with a magnetic dipole, RP effects are expected to be non-deterministic [37]. RP recombination implies the influence of four kinds of interactions: hyperfine interaction, inter-radical exchange interaction, electronic Zeeman interaction and the resonance effect [38]. Each interaction presents its own restrictions imposed by the participating elements and by the lifetime of radicals. In this sense, Hore [39] warns that the effect of reproducible radical pairs on biomolecular systems should not be taken to imply a similar effect at the cellular or whole-organism level. Albuquerque et al. [37] put some restrictions on the RP mechanism related to the growth of cells in an SMF, which seems to occur only in a weak SMF.

Associated with this action model is the production of free radicals (FRs) by an SMF in cells, increasing their concentration, which provokes oxidative stress and, as a result, damages the ion channels, leading to changes in cell morphology and the expression of different genes and proteins [40].

\subsection{Ion Cyclotron Resonance (ICR)—Ion Paramagnetic Resonance (IPR) and Ion Interference (II)}

Ion cyclotron resonance (ICR) is an action model in which ions should circulate in a plane perpendicular to an external MF (SMF or OMF) with Larmor frequencies and respective harmonics [41]. Due to the fact that ions like $\mathrm{Ca}^{2+}, \mathrm{Na}^{+}$and $\mathrm{Mg}^{2+}$ are implicated in biochemical reactions. So, any biological response is then expected to depend on the ratio of the frequency of the OMF to the flux density of the SMF, both at weak values [42]. However, Bingi [35] doubt the effectiveness of the action model, arguing that the coincidence in the case of calcium with a resonance frequency does not allow extrapolation to other ions. On the other hand, the IPR is an action model derived from ICR with the difference that it considers the cyclotron and subharmonic frequencies. However, quantic coherence and decoupled temperature in specifics reactions are required for both mechanisms [42].

The II action model is normally applied in rotating ion-protein complexes, where an SMF induces an inhomogeneous density pattern that begins to rotate with the cyclotron frequency. The addition of an OMF results in the cessation of rotation and finally in the release of the bound ion, a process that may elicit a biological response [42] for example, in calcium-binding protein that can bind to and regulate a multitude of different protein targets, thereby affecting many different cellular functions [41].

\subsection{Stochastic Resonance (SR)}

This action model suggests that noise tuning can be incorporated in a system to maximize the signal-to-noise ratio, in order to take into account underlying effects in mono and bistable systems [35]. There are no reports of the application of this action model in foods but there are some studies related to enzymes in biological systems related to medicine.

\subsection{Membrane Channels}

Rosen [43] indicated that a moderate-intensity SMF can influence the properties of membrane channels (MCs) by changing calcium ion flux deforming or embedding ion channels, thereby altering their activation kinetics. A similar effect was reported for sodium channels, although to a lesser degree. The distinct sensitivity of ion channels to MFs may also be governed by the geometry of the ion pore and/or the presence of a voltage sensor, as in voltage-gated ion channels [44].

\subsection{DNA Interaction}

MFs can interact with DNA directly (breaking its structure), for example, when a PMF of $3 \mathrm{~T}$ with 30 pulses is applied to Bacillus subtilis [32] and indirectly (free radicals), when reacts with nucleic acids, causing damage to DNA. Also decreases in carbohydrate metabolism and energy metabolism through the formation of different types of expressed up-regulated and down-regulated proteins were identified by proteomics, which explains the death of cells [45]. 


\subsection{Changes in Water Properties}

Biological systems are mainly composed of water, which can change its properties and structure when interacting with an MF. This interaction should increase the chemical activity or hydration of proteins and other cellular structures [46]. Rai [47] considered the size of the ions and mentioned that small cations like $\mathrm{Na}^{+}$are fully hydrated in dense, reactive and weakly bound water, while large cations like $\mathrm{K}^{+}$are individually hydrated in water that is less dense and viscous. In relation to this, an MF could affect this behavior of the cells in six ways: (a) by inducing cytoplasmic ionic partitioning, (b) by changing cytoplasmic organization, (c) through changes in cellular proteins, (d) by alteration of the enzymatic activity, (e) by changing the behavior of the active transport and (f) by altering the formation of biopolymers. These events are closely related to the physiology of food fresh; however, no clear direction is indicated to find results that allow the conservation of fresh food.

\subsection{Protein Structure and Functionality}

Brizhik [34] reported that an MF influenced system redox named solitons, which are electrons that are self-trapped in alpha-helical polypeptides due to the moderately strong electron-lattice interaction, resulting in non-thermal resonant effects that affect the metabolism of the organism in general. Bingi [35] proposed ion-protein dissociation, where an ion can enter a protein cavity containing a ligand but an MF disturbs this equilibrium redistribution in the ion cloud, causing different biological responses. Moreover, the structural changes [13,14] modify biological functionality.

The main action models proposed are summarized and illustrate in Figures 1-3.

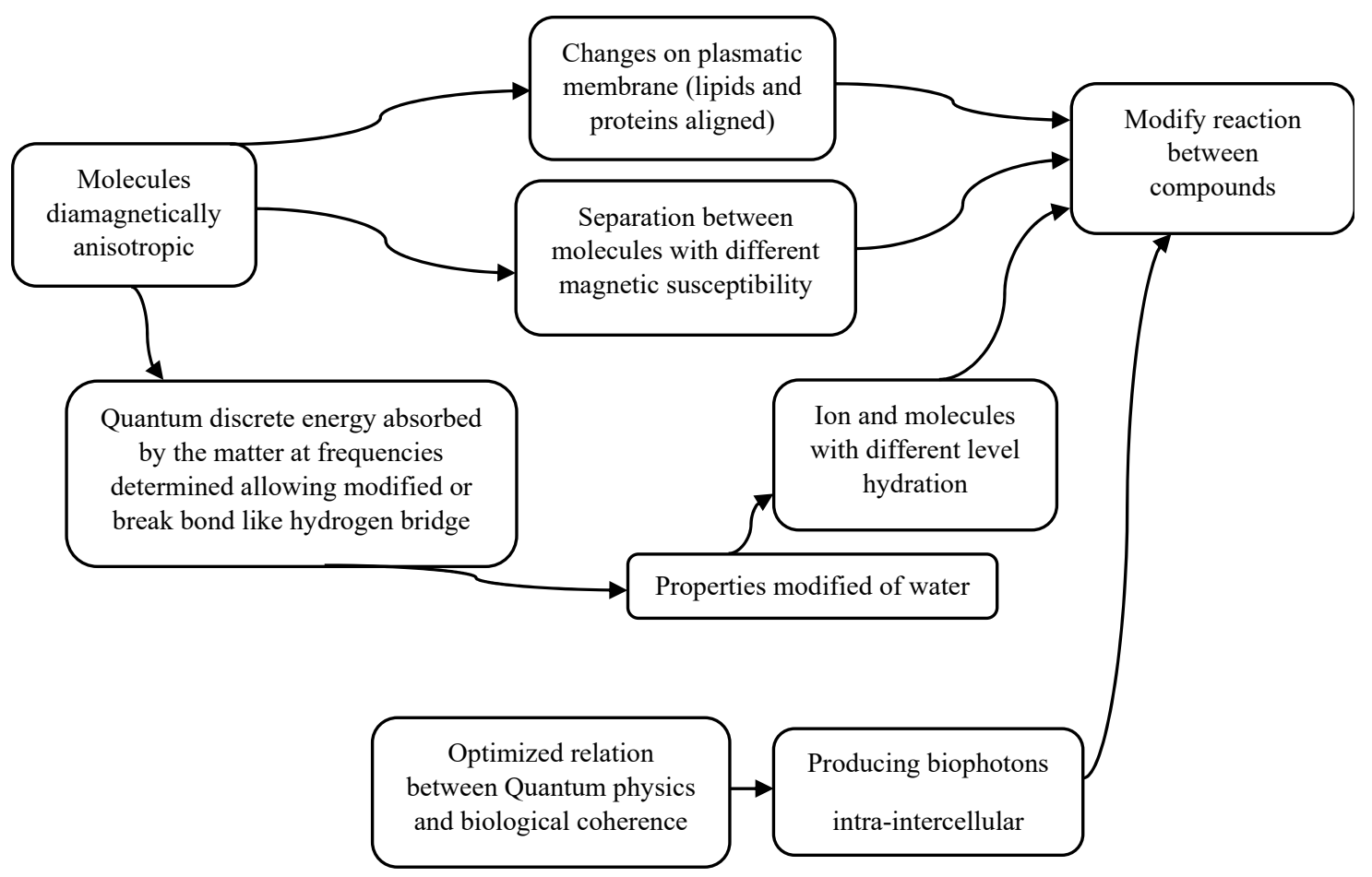

Figure 1. Action models of magnetic fields on physicochemical characteristics of foods. 


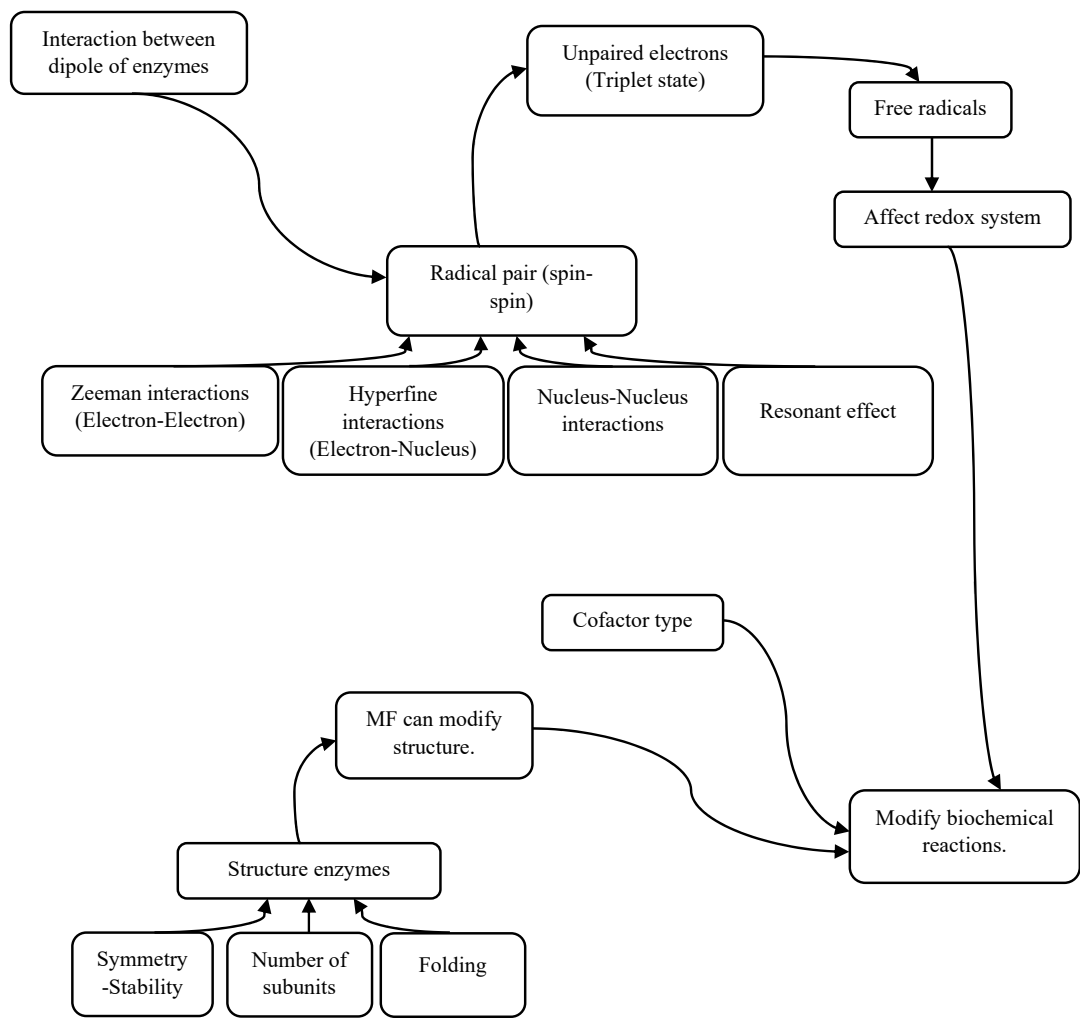

Figure 2. Action models of magnetic fields on enzymes of foods.

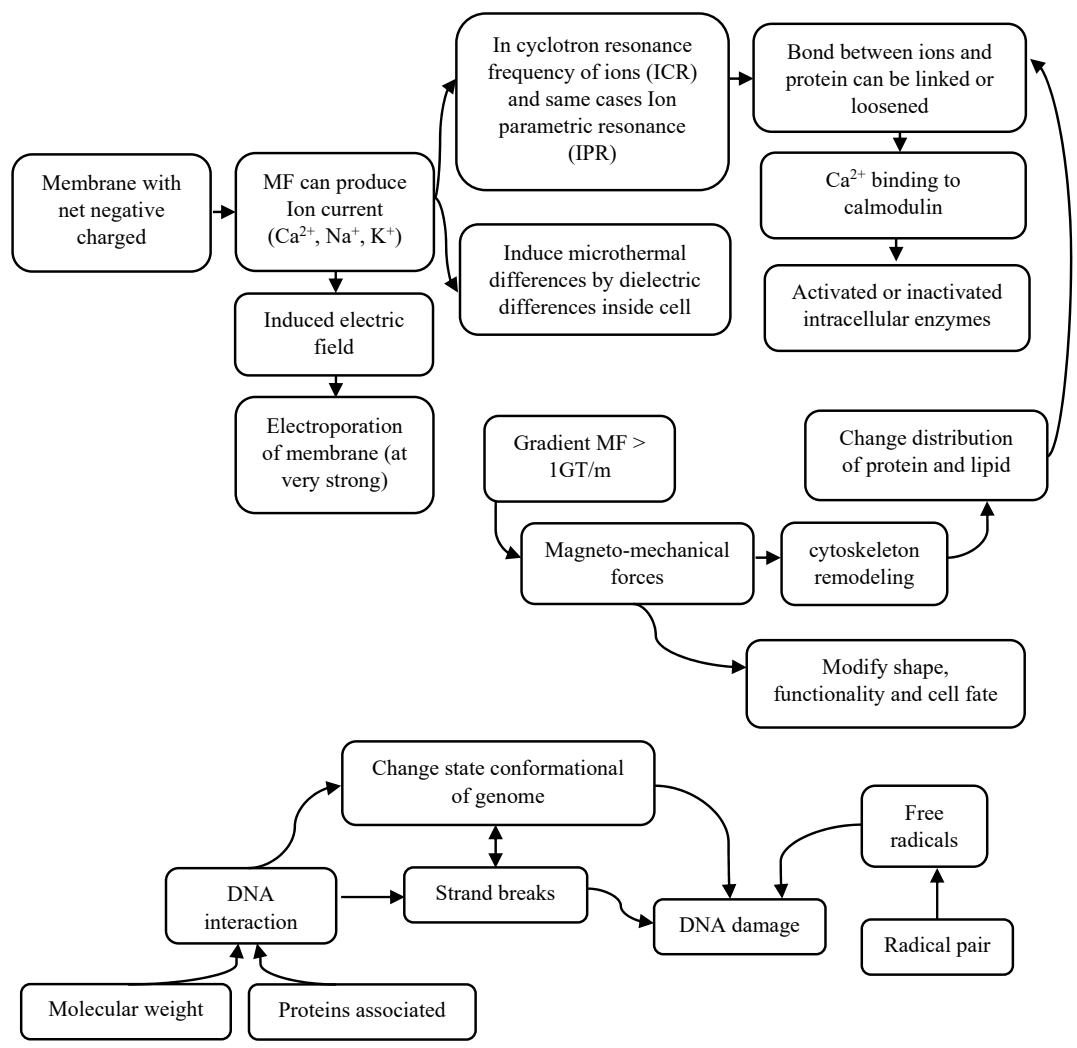

Figure 3. Action models of magnetic fields (MF) on microorganisms of foods. 


\section{Conclusions and Perspectives}

MFs applied in different frameworks lead to promising results in the transformation and preservation of some foods with respect to their physicochemical, enzymatic and microbiological characteristics. As the food industry includes various food types, further studies are required to elucidate the levels and factors to be tuned to obtain specific results and also to understand the underlying action models. Until now, the action models that have been related to the biological systems like foods are the radical pair mechanism, ion cyclotron resonance, the formation of free radicals and structural changes of proteins and DNA.

To understand the effects of MFs on foods it is necessary to determine the magnetic and electric properties of food components and to conduct research both at the quantum level and at compound and system level, which today can be supported by various instrumental techniques and assisted by disciplines such as spintronic, bioinformatics and proteomics, among others. All these techniques will be useful to test different hypotheses and models regarding the action of the magnetic field in food.

Since the action of the magnetic field on food is non-invasive, such technology becomes very interesting in terms of food processes and improve food quality attributes by acting in its different aspects from the physical-chemical to microbiological level.

Author Contributions: H.L.A.M.: Methodology, Investigation; E.J.X.C.: Conceptualization, Supervision, Writing-Original draft preparation, Methodology, Funding acquisition; S.S.: Visualization, Investigation, Writing-Review \& Editing; A.C.d.S.S.: Formal analysis, Investigation Validation, Writing-Review \& Editing. All authors have read and agreed to the published version of the manuscript.

Funding: This research was funded by FONDECYT-CONCYTEC (grant contract number 271-2015-FONDECYT), the São Paulo Research Foundation (FAPESP, Brazil) grant number 2018/05871-3, CNPq proc. Num. 305295/2018-7.

Conflicts of Interest: The authors declare no conflict of interest.

\section{References}

1. Grigelmo-Miguel, N.; Soliva-Fortuny, R.; Barbosa-Cánovas, G.; Martín-Belloso, O. Use of Oscillating Magnetic Fields in Food Preservation. In Nonthermal Processing Technologies for Food, 1st ed.; Zhang, H.Q., Barbosa-Cánovas, G.V., Balasubramaniam, V.M., Dunne, C.P., Farkas, D.F., Yuan, J.T.C., Eds.; Wiley-Blackwell: Ames, IA, USA, 2011; p. 675.

2. Maki, S.; Hirota, N. Magnetic separation technique on binary mixtures of sorbitol and sucrose. J. Food Eng. 2014, 120, 31-36. [CrossRef]

3. Gupta, M.K.; Anand, A.; Paul, V.; Dahuja, A.; Singh, A.K. Reactive oxygen species mediated improvement in vigour of static and pulsed magneto-primed cherry tomato seeds. Indian J. Plant Physiol. 2015, 20, 197-204. [CrossRef]

4. Eşitken, A.; Turan, M. Alternating magnetic field effects on yield and plant nutrient element composition of strawberry ( Fragaria x ananassa cv. camarosa). Acta Agric. Scand. Sect. B-Soil Plant Sci. 2004, 54, 135-139. [CrossRef]

5. Jia, J.; Wang, X.; Lv, J.; Gao, S.; Wang, G. Alternating Magnetic Field Prior to Cutting Reduces Wound Responses and Maintains Fruit Quality of Cut cucumis melo L. cv Hetao. Open Biotechnol. J. 2015, 9, 230-235. [CrossRef]

6. Goldschmidt Lins, P.; Aparecida Silva, A.; Marina Piccoli Pugine, S.; Ivan Cespedes Arce, A.; José Xavier Costa, E.; De Pires Melo, M. Effect of Exposure to Pulsed Magnetic Field on Microbiological Quality, Color and Oxidative Stability of Fresh Ground Beef. J. Food Process Eng. 2016. [CrossRef]

7. Sakdatorn, V.; Thavarungkul, N.; Srisukhumbowornchai, N.; Intipunya, P. Improvement of rheological and physicochemical properties of longan honey by non-thermal magnetic technique. Int. J. Food Sci. Technol. 2018, 53, 1717-1725. [CrossRef]

8. Otero, L.; Rodríguez, A.C.; Pérez-Mateos, M.; Sanz, P.D. Effects of Magnetic Fields on Freezing: Application to Biological Products. Compr. Rev. Food Sci. Food Saf. 2016, 15, 646-667. [CrossRef]

9. Zhao, H.; Zhang, F.; Hu, H.; Liu, S.; Han, J. Experimental study on freezing of liquids under static magnetic field. Chin. J. Chem. Eng. 2017, 25, 1288-1293. [CrossRef] 
10. Ali Hayder, I.; Al-HilphyAsaad, R.S.; Al-Darwash, A.K. The effect of magnetic field treatment on the characteristics and yield of Iraqi local white cheese. IOSR J. Agric. Vet. Sci. 2015, 8, 63-69. [CrossRef]

11. Zaguła, G.; Puchalski, C. Changes in Glucose And Fructose in Apples Exposed To Constant And Slowly Changing Magnetic Fields. Zywnosc Nauka Technol. Jakosc/Food Sci. Qual. 2013. [CrossRef]

12. Jia, S.; Liu, Y.; Wu, S.; Wang, Z. Effect of static magnetic field on $\alpha$-amylase activity and enzymatic reaction. Trans. Tianjin Univ. 2009, 15, 272-275. [CrossRef]

13. Ma, H.; Huang, L.; Zhu, C. The effect of pulsed magnetic field on horseradish peroxidase. J. Food Process Eng. 2011, 34, 1609-1622. [CrossRef]

14. Buchachenko, A. Why magnetic and electromagnetic effects in biology are irreproducible and contradictory? Bioelectromagnetics 2016, 37, 1-13. [CrossRef] [PubMed]

15. Çelik, Ö.; Büyükuslu, N.; Atak, Ç.; Rzakoulieva, A. Effects of magnetic field on activity of superoxide dismutase and catalase in Glycine max (L.) Merr. roots. Polish J. Environ. Stud. 2009, 18, 175-182.

16. Mizuki, T.; Sawai, M.; Nagaoka, Y.; Morimoto, H.; Maekawa, T. Activity of Lipase and Chitinase Immobilized on Superparamagnetic Particles in a Rotational Magnetic Field. PLoS ONE 2013, 8, e66528. [CrossRef] [PubMed]

17. Mizuki, T.; Watanabe, N.; Nagaoka, Y.; Fukushima, T.; Morimoto, H.; Usami, R.; Maekawa, T. Activity of an enzyme immobilized on superparamagnetic particles in a rotational magnetic field. Biochem. Biophys. Res. Commun. 2010, 393, 779-782. [CrossRef] [PubMed]

18. Barbosa-Canovas, G.V.; Schaffner, D.W.; Pierson, M.D.; Zhang, Q.H. Oscillating Magnetic Fields. J. Food Sci. 2000, 65, 86-89. [CrossRef]

19. Liu, Z.; Gao, X.; Zhao, J.; Xiang, Y. The Sterilization Effect of Solenoid Magnetic Field Direction on Heterotrophic Bacteria in Circulating Cooling Water. Procedia Eng. 2017, 174, 1296-1302. [CrossRef]

20. Ji, W.; Huang, H.; Deng, A.; Pan, C. Effects of static magnetic fields on Escherichia coli. Micron 2009, 40, 894-898. [CrossRef]

21. Strašák, L.; Vetterl, V.; Šmarda, J. Effects of low-frequency magnetic fields on bacteria Escherichia coli. Bioelectrochemistry 2002, 55, 161-164. [CrossRef]

22. Wu, P.; Qu, W.; Abdualrahman, M.A.Y.; Guo, Y.; Xu, K.; Ma, H. Study on inactivation mechanisms of Listeria grayi affected by pulse magnetic field via morphological structure, $\mathrm{Ca}^{2+}$ transmembrane transport and proteomic analysis. Int. J. Food Sci.Technol. 2017, 52, 2049-2057. [CrossRef]

23. Bayraktar, V.N. Magnetic field effect on yeast saccharomyces cerevisiae activity at grape must fermentation. Biotechnol. Acta 2013, 6, 125-137. [CrossRef]

24. da Motta, M.A.; Muniz, J.B.F.; Schuler, A.; da Motta, M. Static Magnetic Fields Enhancement of Saccharomyces cerevisae Ethanolic Fermentation. Biotechnol. Prog. 2008, 20, 393-396. [CrossRef]

25. Iwasaka, M.; Ikehata, M.; Miyakoshi, J.; Ueno, S. Strong static magnetic field effects on yeast proliferation and distribution. Bioelectrochemistry 2004, 65, 59-68. [CrossRef] [PubMed]

26. Alvarez, D.C.; Pérez, V.H.; Justo, O.R.; Alegre, R.M. Effect of the extremely low frequency magnetic field on nisin production by Lactococcus lactis subsp. lactis using cheese whey permeate. Process Biochem. 2006, 41, 1967-1973. [CrossRef]

27. Haile, M.; Pan, Z.; Gao, M.; Luo, L. Efficacy in Microbial Sterilization of Pulsed Magnetic Field Treatment. Int. J. Food Eng. 2008, 4. [CrossRef]

28. Harte, F.; Martin, M.F.S.; Lacerda, A.H.; Lelieveld, H.L.M.; Swanson, B.G.; Barbosa-Cánovas, G.V. Potential use of 18 tesla static and pulsed magnetic fields on escherichia coli and saccharomyces cerevisiae. J. Food Process. Preserv. 2001, 25, 223-235. [CrossRef]

29. He, R.; Ma, H.; Wang, H. Inactivation of E. coli by high-intensity pulsed electromagnetic field with a change in the intracellular $\mathrm{Ca}^{2+}$ concentration. J. Electromagn. Waves Appl. 2014, 28, 459-469. [CrossRef]

30. Ahmed, I.; Istivan, T.; Cosic, I.; Pirogova, E. Evaluation of the effects of Extremely Low Frequency (ELF) Pulsed Electromagnetic Fields (PEMF) on survival of the bacterium Staphylococcus aureus. EPJ Nonlinear Biomed. Phys. 2013, 1, 5. [CrossRef]

31. Novák, J.; Strašák, L.; Fojt, L.; Slaninová, I.; Vetterl, V. Effects of low-frequency magnetic fields on the viability of yeast Saccharomyces cerevisiae. Bioelectrochemistry 2007, 70, 115-121. [CrossRef]

32. Qian, J.; Zhou, C.; Ma, H.; Li, S.; Yagoub, A.E.A.; Abdualrahman, M.A.Y. Biological Effect and Inactivation Mechanism of Bacillus subtilis Exposed to Pulsed Magnetic Field: Morphology, Membrane Permeability and Intracellular Contents. Food Biophys. 2016, 11, 429-435. [CrossRef] 
33. Gao, M.; Zhang, J.; Feng, H. Extremely low frequency magnetic field effects on metabolite of Aspergillus niger. Bioelectromagnetics 2011, 32, 73-78. [CrossRef] [PubMed]

34. Brizhik, L. Biological effects of pulsating magnetic fields: Role of solitons. arXiv 2014, arXiv:1411.6576.

35. Bingi, V.N.; Savin A, V. Effects of weak magnetic fields on biological systems: Physical aspects. Physics-Uspekhi 2003, 46, 259-291. [CrossRef]

36. Mousavian-Roshanzamir, S.; Makhdoumi-Kakhki, A. The Inhibitory Effects of Static Magnetic Field on Escherichia coli from two Different Sources at Short Exposure Time. Rep. Biochem. Mol. Biol. 2017, 5, 112-116. [PubMed]

37. Albuquerque, W.W.C.; Costa, R.M.P.B.; de Salazar e Fernandes, T.; Porto, A.L.F. Evidences of the static magnetic field influence on cellular systems. Prog. Biophys. Mol. Biol. 2016, 121, 16-28. [CrossRef]

38. Steiner, U.E.; Ulrich, T. Magnetic field effects in chemical kinetics and related phenomena. Chem. Rev. 1989, 89, 51-147. [CrossRef]

39. Hore, P.J. Are biochemical reactions affected by weak magnetic fields? Proc.Natl. Acad. Sci. USA 2012, 109, 1357-1358. [CrossRef]

40. Ghodbane, S.; Lahbib, A.; Sakly, M.; Abdelmelek, H. Bioeffects of Static Magnetic Fields: Oxidative Stress, Genotoxic Effects, and Cancer Studies. Biomed Res. Int. 2013, 2013, 1-12. [CrossRef]

41. Pothakamury, U.R.; Barbosa-Canovas, G.V.; Swanson, B.G. Magnetic-field inactivation of microorganisms and generation of biological changes. Food Technol. 1993, 47, 85-93.

42. Pazur, A.; Schimek, C.; Galland, P. Magnetoreception in microorganisms and fungi. Open Life Sci. 2007, 2,597-659. [CrossRef]

43. Rosen, A.D. Studies on the Effect of Static Magnetic Fields on Biological Systems. Piers Online 2010, 6, 133-136. [CrossRef]

44. Tolosa, M.F.; Bouzat, C.; Cravero, W.R. Effects of static magnetic fields on nicotinic cholinergic receptor function. Bioelectromagnetics 2011, 32, 434-442. [CrossRef]

45. Qian, J.; Zhou, C.; Ma, H.; Li, S.; Yagoub, A.E.A.; Abdualrahman, M.A.Y. Proteomics Analyses and Morphological Structure of Bacillus subtilis Inactivated by Pulsed Magnetic Field. Food Biophys. 2016, 11, 436-445. [CrossRef]

46. Torgomyan, H.; Trchounian, A. Bactericidal effects of low-intensity extremely high frequency electromagnetic field: An overview with phenomenon, mechanisms, targets and consequences. Crit. Rev. Microbiol. 2013, 39, 102-111. [CrossRef] [PubMed]

47. Ratter, J. The Brazilian Cerrado Vegetation and Threats to its Biodiversity. Ann. Bot. 1997, 80, $223-230$. [CrossRef]

(C) 2020 by the authors. Licensee MDPI, Basel, Switzerland. This article is an open access article distributed under the terms and conditions of the Creative Commons Attribution (CC BY) license (http://creativecommons.org/licenses/by/4.0/). 